\title{
Program Deradikalisasi Radikalisme dan Terorisme Melalui Nilai-Nilai Luhur Pancasila
}

\author{
Fuadi Isnawan \\ Fakultas Hukum Universitas Islam Indonesia \\ Alamat E-Mail: fuadi.isnawan@gmail.com
}

\begin{abstract}
Deradicalisation is every effort to neutralize radical ideals through interdisciplinary approaches, such as law, psychology, religion, economics, education, humanity and socio-culture for those who are influenced or exposed to radical and / or pro-violence. Implementation of Deradicalization Program (Development) can be done through Deradicalization in Prisons with the Target of terrorism prisoners who are in prison by identifying, Rehabilitation, Reeducation and Resosialisation. Deradicalisation has a goal, among other things, to restore the actors involved who have a radical understanding to return to a more moderate mindset. Deradicalisation of terrorism is very important because terrorism has become a serious problem for the international community because at any time it will endanger the national security for the country hence deradicalization program is needed as a formula of prevention and prevention of radical understanding like terrorism.
\end{abstract}

Keywords: deradicalisation, terrorism, development

\section{Abstrak}

Deradikalisasi adalah segala upaya untuk menetralisir paham-paham radikal melalui pendekatan interdisipliner, seperti hukum, psikologi, agama, ekonomi, pendidikan, kemanusiaan dan sosial-budaya bagi mereka yang dipengaruhi atau terekspose paham radikal dan/atau prokekerasan. Implementasi Program Deradikalisasi (Pembinaan) dapat dilakukan melalui Deradikalisasi di dalam Lapas dengan Sasaran narapidana terorisme yang berada di dalam lapas dengan melakukan identifikasi, Rehabilitasi, Reedukasi dan Resosialisasi. Deradikalisasi mempunyai tujuan antara lain 
untuk mengembalikan para aktor terlibat yang memiliki pemahaman radikal untuk kembali kejalan pemikiran yang lebih moderat. Deradikalisasi tindak pidana terorisme sangatlah penting mengingat terorisme telah menjadi permasalahan serius bagi dunia internasional karena setiap saat akan membahayakan keamanan nasional bagi negara maka dari itu program deradikalisasi dibutuhkan sebagai formula penanggulangan dan pencegahan pemahaman radikal seperti terorisme.

Kata Kunci: deradikalisasi, terorisme, pembinaan.

\section{A. Pendahuluan}

\section{Latar Belakang}

Maraknya tindak pidana terorisme yang terjadi akhir akhir ini jelas membuat masyarakat merasa resah. Secara mudah, terorisme dapat dimaknai sebagai serangan serangan terkoordinasi yang bertujuan membangkitkan perasaan teror terhadap sekelompok masyarakat. Sebagian besar para teroris biasanya menggunakan kekerasan untuk menimbulkan rasa takut, biasanya untuk tujuan tertentu yang telah mereka rencanakan, misalnya politik, mereka sudah terkapar dengan radikalisme. Radikalisme memiliki arti paham atau aliran yang menginginkan perubahan atau pembaharuan sosial dan politik dengan cara kekerasan atau dengan sikap yang ekstrem.

Radikalisme merupakan diskursus global yang dilakukan sebagai tindakan mengajak para teroris dan pendukungnya untuk penggunaan kekerasan dalam pencapaian tujuan tertentu yang memiliki legitimasi doktrin agama. Oleh karenanya, radikalisme agama 
dianggap menjadi penyebab serangkaian aksi terorisme di berbagai belahan dunia. ${ }^{1}$

Para pelaku terorisme sejak peristiwa World Trade Center (WTC) di Amerika Serikat pada 11 September 2001 mengaku aksi yang dilakukannya termasuk sebagai bentuk jihad fisabilillah, sebagaimana pengakuan Ali Imron dalam aksi bom Bali yang dipengaruhi adanya beberapa alasan, yaitu ketidakpuasan terhadap pemerintah yang tidak berdasarkan syari'at Islam dan tidak adanya imamah, rusaknya moralitas dan akidah masyarakat, melindungi umat Islam, pembalasan terhadap kafir yang memerangi kaum muslim. ${ }^{2}$

Salah satu contoh peristiwa yang sedang hangat adalah Bom di Gereja Surabaya. Kejadian teror yang menimpa warga Surabaya khususnya bagi umat kristen di Gereja Kristen Indonesia, Gereja Santa Maria, dan Gereja Pantekosta membuat seluruh masyarakat berduka dan mengutuk keras praktek terorisme yang selama ini menjadi musuh berat pemerintah. Sebagaimana laporan Tempo.co $(13 / 05 / 18)$ bom bunuh diri di tiga gereja yang ada di Surabaya sudah memakan korban 49 jiwa, ada 9 orang yang mati dan 40 yang luka-luka. Menurut laporan Wakapolrestabes Surabaya, Ajun (Komisaris Besar Benny Pramono) diduga bom tersebut diledakkan oleh satu keluarga yang melibatkan istri dan anaknya. Pasca bom di tiga gereja kemudian bom susulan terus terjadi yaitu di Rumah Susun Wonocolo, Sidoarjo (13/05/18) pada pukul 20.30 Wib, dan di Markas Kepolisian Resor Kota Besar (Mapolrestabes)

${ }^{1}$ Muh. Khamdan, Rethinking Deradikalisasi : Konstruksi Bina Damai Penanganan Terorisme, Jurnal ADDIN, Vol. 9, No. 1, Februari 2015, Jurnal STAIN Kudus, HIm 182.

${ }^{2}$ Ali Imron, Ali Imron Sang Pengebom (Jakarta: Republika, 2007), hlm. 41 .

Fikri, Vol. 3, No. 1, Juni 2018 
Surabaya, senin (14/05/18) pada pukul 10.05 Wib. Setidaknya kejadian bom susulan memberikan isarat bahwa penanganan terhadap terorisme harus benar-benar totalitas. Kejadian teror ini seperti memutar kembali kejadian di Mako Brimob tempo hari (10/05/18), ada dua orang wanita yang masih kecil diduga akan melakukan aksi penusukan terhadap anggota Brimob (Brigade Mobil) sebagaimana laporan Biro Penerangan Masyarakat Divisi Humas Polri Brigadir Jenderal M. Iqbal. Itu artinya, pelaku teror tidak ada hubungannya dengan usia, siapapun bisa melakukan aksi bom bunuh diri jika telah terperangkap oleh gerakan ISIS. Karena apa yang mereka lakukan sama sekali tidak menggambarkan nilai nilai islam yang dilandaskan pada Al Quran dan As Sunnah. ${ }^{3}$ Pelaku teror ini menurut Jenderal Tito Karnavian adalah seorang Pimpinan Jamaah Ansharut Daulah (JAD) Surabaya, yang salah satu pimpinannya terjerat kasus pidana teroris yaitu Aman Abdurrahman kini mendekam di LP Nusakambangan. Menurut polisi di balik serangan teror di Surabaya diduga kuat sebagai pembalasan setelah ISIS terdesak di tingkat internasional. ${ }^{4}$

Tindakan tersebut dipicu oleh radikalisme. Radikalisme itu sendiri dapat dimaknai sebagai sebuah pandanagan yang mempunyai keinginan untuk melakukan suatu perubahan yang mendasar (fundamental) sesuai dengan interpretasi ideologi yang dianut mereka ataupun

${ }^{3}$ Muhammad Agus Mushodiq dan Suhono, “Ajaran Islam Nusantara Di Dalam Kamus Santri Tiga Bahasa Indonesia-Inggrisarab Karya Slamet Riyadi Dan Ainul Farihin (Studi Analisis Semiotika Dan Konsep Pribumisasi Islam Abdurrahman Wahid)," Jurnal Bahasa Lingua Scientia 9, no. 2 (2017): 210, https://doi.org/10.21274/ls.2017.9.2.209-240.

${ }^{4}$ Jejen Aqin, Bom Surabaya dan Upaya Pemerintah Melawan Terorisme, diakses dari https://geotimes.co.id/opini/bom-surabaya-danupaya-pemerintah-melawan-terorisme/, diakses tanggal 28 Juni 2018 pukul 09.30 WIB. 
realitas sosial yang ada. Perubahan yang secara radikal tersebut dapat dilakukan dengan cara persuasive atau ajakan yang damai tetapi juga dapat dengan kekerasan fisik ataupun kekerasan simbolik. Pada akhirnya dapat disimpulkan bahwa radikalisme cenderung identik dengan tindak kekerasan bahkan sampai pada bunuh diri menuju kebermaknaan hidup yang diyakininya. ${ }^{5}$

Badan Nasional Penanggulangan Terorisme (BNPT) menyelenggarakan beberapa program, salah satunya yaitu deradikalisasi. Deradikalisasi adalah sebuah program yang bertujuan untuk menetralkan pemikiran-pemikiran bagi mereka yang sudah terkapar dengan radikalisme. Yang menjadi sasarannya yaitu para teroris yang ada di dalam lapas maupun di luar lapas.

Deradikalisasi memiliki tujuan untuk menetralisir pemikiran radikalisme. Maksudnya, untuk membersihkan pemikiran-pemikiran radikalisme yang ada pada para teroris sehingga mereka bisa kembali menjadi masyarakat biasa sebagaimana masyarakat lainnya.

\section{Rumusan Masalah}

Berdasarkan latar belakang masalah yang telah diuraikan, maka penulis dapat menarik beberapa hal yang akan dijadikan sebagai rumusan masalah, yaitu :

a. Mengapa gerakan radikalisme banyak sekali bermunculan di Indonesia zaman sekarang?

b. Bagaimana upaya penggunaan nilai - nilai luhur Pancasila dalam mencegah tindak pidana terorisme?

\section{Metode Penelitian}

${ }^{5}$ Petrus Reinhard Golose, Deradikalisasi Terorisme: Humanis, Soul Approach, dan Menyenuh Akar Rumput (Jakarta: Yayasan Pengembangan Kajian Ilmu Kepolisian, 2009), hlm. 38. 
Penelitian ini akan disusun dengan menggunakan tipe penelitian yuridis-normatif, yaitu penelitian yang difokuskan untuk mengkaji penerapan kaidah-kaidah atau norma-norma dalam hokum positif. ${ }^{6}$

Yuridis-Normatif, yaitu pendekatan yang menggunakan konsepsi legis positivis. Konsep ini memandang hokum identik dengan norma-norma tertulis yang dibuat dan diundangkan oleh lembaga atau pejabat yang berwenang. Konsepsi ini memandang hokum sebagai suatu system normatif yang bersifat mandiri, tertutup dan terlepas dari kehidupan masyarakat yang nyata. ${ }^{7}$

Pengkajian permasalahan di dalam penelitian ini dipusatkan pada dua pokok permasalahan, yaitu penyebab aliran radikal dan terorisme berkembang subur di Indonesia dan Penggunaaan nilai - nilai luhur Pncasila sebagai asas hokum tertinggi untuk mencegah tindakan terorisme dan radikalisme.

Data dalam penulisan ini adalah data sekunder, yaitu bahan pustaka yang mencakup dokumen-dokumen resmi, buku-buku perpustakaan, peraturan perundang-undangan, karya ilmiah, artikel-artikel, serta dokumen yang berkaitan dengan materi penelitian.

\section{B. Kerangka Konsep}

\section{Konsep Terorisme dan Radikalisme}

Kata "teroris" (pelaku) dan terorisme (aksi) berasal dari kata Latin 'terrere' yang kurang lebih berarti membuat gemetar atau menggetarkan, dan kata teror juga bisa menimbulkankengerian. Dan dalam Kamus Besar Bahasa

${ }^{6}$ Johnny Ibrahim, Teori dan MetodologiPenelitianHukumNormatif, (Malang:Bayumedia Publishing, 2006), hlm. 295.

${ }^{7}$ Ronny HanitijoSoemitro, MetodologiPenelitianHukum dan Jurimetri, (Jakarta: Ghalia Indonesia, 1988), hlm. 13-14. 
Indonesia (KBBI), teror yaitu usahamenciptakan ketakutan, kengerian, dan kekejaman oleh seseorang atau golongan; danterorisme yaitu penggunaan kekerasan untuk menimbulkan ketakutan dalam usaha mencapaitujuan (terutama tujuan politik). ${ }^{8}$

Kata Teror dalam Kamus Besar Bahasa Indonesia, dapat diartikan sebagai kegiatan yang menciptakanketakutan, kengerian, atau kekejaman oleh seseorang atau golongan. Terroris adalah orang yangmenggunakan kekerasan untuk menimbulkan rasa takut, biasanya untuk tujuan politik. Terrorisme adalah penggunaan kekerasan terhadap sasaran sipil untuk menimbulkanketakutan sebagai usaha untuk mencapai suatu tujuan (terutama tujuan politik). ${ }^{9}$

Menurut Hukum Positif Indonesia: UU No:15 Tahun 2003, Bab III pasal: 6, dikemukakan: "bahwasetiap orang yang dengan sengaja menggunakan kekerasan atau ancaman kekerasan menimbulkan suasanateror atau rasa takut terhadap orang secara meluas atau menimbulkan korban yang bersifat massal dengancara merampas kemerdekaan atau hilangnya nyawa dan harta benda orang lain atau mengakibatkankerusakan atau kehancuran terhadap objekobjek vital yang strategis atau lingkungan hidup atau fasilitaspublik atau internasional" diancam dengan pidana hukuman mati, penjara seumur hidup atau penjara 4 tahunhingga 20 tahun. $^{10}$

${ }^{8}$ Abdul Wahid, et.al. Kejahatan Terorisme - Perspektif Agama, HAM dan Hukum.(Bandung : PT Refika Aditama, 2004), hlm.22

9 Departemen Pendidikan dan Kebudayaan. Kamus Besar Bahasa Indonesia , (Edisi Kedua), (Jakarta : Balai Pustaka, 1995), hlm $1048 .$.

${ }^{10}$ Yosaphat Haris Nusarastriya, Radikalisme dan Terorisme di Indonesia dari Masa ke Masa (Tinjauan dari Perspektif Kewarganegaraan), Jurnal Pax Humana Vol 2, No 2 Mei 2015, (Yayasan Bina Dharma : Salatiga), hlm 2 . 
Pendapat lain dikemukakan juga oleh Ezzat A. Fattah, Profesor dan ahli kriminologi asal Kanada, mengatakan bahwa Terorisme berasal dari kata teror, yang berasal dari bahasa latin yaitu "terrere" yang berarti rasa takut. Awalnya kata "teror" digunakan untuk menggambarkan cara untuk memerintah, dan kata 'terorisme" digunakan untuk menggambarkan penggunaan sistematik teror dari pemerintah sebagai alat koersi untuk menekan kepatuhan terhadap pemerintah. $^{11}$

Kata radikalisasi sering digunakan untuk menggambarkan proses dimana individu mentransformasi pandangan mereka terhadap dunia dari kondisi suatu masyarakat yang cenderung "normal" menuju masyarakat yang cenderung "ekstrim". Dalam beberapa kasus, individu tersebut kemudian akan melibatkan diri mereka dalam tahap berikutnya yaitu melakukan tindakan-tindakan kekerasan. ${ }^{12}$ Radikalisasi tidak hanya dimotivasi oleh suatu landasan ideologi tapi juga dipengaruhi oleh faktor lain. Sebagai contoh, kasus terorisme pada awal tahun 2016, Afif alias Sunakim merupakan residivis kasus pelatihan perang dan kepemilikan senjata api. Afif diduga merupakan salah satu pelaku teroris yang tewas dalam aksi teror bom di Jalan $\mathrm{MH}$ Thamrin, Jakarta Pusat. Afif diketahui berusia 32 tahun dan berasal dari Sumedang, Jawa Barat. Afif merupakan anak didik langsung Sulaiman Aman Abdurahman orang yang mengklaim sebagai amir negara Islam Irak dan Suriah (ISIS) di Asia Tenggara. Pada tahun 2010, Densus 88 Antiteror pernah menangkap Afif di Aceh atas perkara pelatihan

${ }^{11}$ Ronny Nitibagaskara, Tegakkan Hukum Gunakan Hukum, (Jakarta: Penerbit Buku Kompas,2006). hlm. 45.

${ }^{12}$ Farid Septian, Pelaksanaan Deradikalisasi Narapidana Terorisme di Lembaga Pemasyarakatan Kelas I Cipinang, Jurnal Kriminologi Indonesia, Vol. 7 No. 1 Mei 2010. Hlm 114. 
perang dan kepemilikan senjata. Afif menjatuhkan hukuman penjara selama tujuh tahun (Harian Sindo, 2016).

Sejarah kekerasan dan radikalisme sering kali membawa nama agama. Hal ini dapat dipahami karena agama memiliki kekuatan yang dahsyat, yang melebihi kekuatan politik, sosial, dan budaya. Agama bahkan bisa diangkat sampai pada tingkat supranatural. Atas nama agama, kemudian radikalisme diabsahkan dalam berbagai tindakan. Mulai dari mengkafirkan orang-orang yang tak sepaham (takfi'r) sampai melakukan pembunuhan terhadap musuh yang tidak seideologi dengannya. ${ }^{13}$ Zallum sebagaimana yang dikutip oleh Fitrono dan Suhono menjelaskan karena pemikiran yang hakiki menurut penganut faham radikal karena adanya sebuah mabda' (ideology) yang menggabungkan fikrah (pemikiran) dan ideologi. ${ }^{14}$

\section{Pemicu Tumbuhnya Radikalisme Islam di Indonesia}

Fakta yang ada tidak dapat disembunyikan bahwa pemahaman sempit, kaku, fanatis, dan keras, misalnya dikalangan kelompok Salafi Jihadis dan aliansinya, mempunyai faktor-faktor pemicu sehingga menjadikan mereka berfaham radikal dan sekaligus ultra revolusionist, yang antara lain berupa faktor:

a. Faktor internal keberagamaan

Hal ini secara khusus terkait dengan pemahaman dan interprestasi terhadap konsep-konsep dasar Islam dan konsepkonsep perjuangan, seperti konsep jihad yang dipahami oleh kelompok radikal Islam yang tidak hanya sebagai bentuk perjuangan dakwah Islam, tetapi lebih jauh dipahami sebagai

${ }^{13}$ Dede Rodin, Islam dan Radikalisme : Telaah Atas Ayat - Ayat Kekerasan Dalam Al-Qur'an, Jurnal ADDIN, Vol. 10, No. 1, Februari 2016, Jurnal STAIN Kudus, hlm 31.

${ }^{14}$ Eko Nani Fitriono dan Suhono Suhono, "Wacana Negara Islam: Kajian Kritis Kontruksi Pemikiran Khilafah Ala Hizbut Tahrir," Ri'ayah: Journal of Social and Religious 2, no. 02 (2017): 46. 
bentuk perlawanan (perang) terhadap musuh-musuh idelogis Islam (kaum kafir). Selain pemahaman dan penekanan dimensi teologisnya, jihad juga dibenturkan dalam dimensi dua kutub teritorial yang berseberangan yakni dār al-Islam dan dār al-harb yang mana dār yang kedua dijadikan sebagai sasaran ekspansi dengan legitimasi jihad untuk menegakkan kalimat Allah di muka bumi baik dengan cara damai ataupun perang.

b. Faktor eksternal sosio-politikultural:

Hegemoni politik, ekonomi dan budaya Barat (non Islam) terhadap umat Islam yang dianggap membahayakan Islam dan umat Islam. Bagi kalangan fundamentalis ide-ide modernisme Barat dianggap telah mendistorsi tradisionalisme mereka. Ketika ide-ide modernisme memasuki ranah kehidupan dan ideologi umat Islam maka harus dilakukan upaya-upaya membendung modernisme karena akan membuat ide-ide tradisional fundamentalis mereka akan menjadi menguat dan mempunyai daya tarik tersendiri, bahkan beberapa penulis melihat bahwa faktor ekonomi, alam yang gersang, dan semacamnya menjadi pemicu munculnya ekspresi gerakan fundamentalisme dalam bentuk perang suci dengan menaklukkan wilayah lain.

c. Faktor Psikologis:

Melalui efikasi radikal dan agresif, yang dalam psikologi politik atau gerakan sosial, seseorang merasa bahwa dirinya penting, punya kemampuan, dan berarti untuk melakukan sesuatu yang diharapkan. Ada optimisme di situ yang merupakan energi psikologis pendorong (psychological driving force) suatu tindakan, yang dalam konteks politiknya dijadikan sebagai konteks aktivitas islamis (Islam gerakan the Islamists). Faktor psikologis ini paling tidak terlihat dalam dua bentuk, yaitu: 
- Alienasi radikal, suatu perasaan terasing seseorang dari lingkungannya. Apa yang terjadi di sekitar lingkungan kehidupannya bertentangan dengan apa yang diyakininya sebagai sesuatu yang harus terjadi. Perasaan alienasi radikal ini pada gilirannya akan berkembang menjadi aktivitas radikal. Perbedaan antara yang diyakininya dengan realitas yang dihadapinya (das sein dan das sollen) dapat terlihat dalam Islam sendiri dengan keyakinan melalui ayat-ayat Alquran yang menyatakan bahwa umat Islam adalah umat terbaik sedangkan dalam realitasnya, terutama dalam kehidupan dunia moderen sekarang, fakta yang muncul menunjukkan bahwa umat Islam masih jauh dari apa yang diharapkan. Kontradiksi antara das sein dan das sollen ini berpotensi menumbuhkan perasaan apologetik untuk menyalahkan kekuatan di luar Islam, karena merasa umat Islam diperlakukan tidak adil, bahkan ditindas dan dimarjinalkan. Konsekuensinya mendorong seseorang menjadi aktivis radikal sebagai wujud protes atas ketidakadilan yang dilakukan oleh kekuatan di luar Islam, termasukkekuatan negara atau pemerintah yang mereka anggap juga telah keluar dari nilai-nilai Islam.

- Perasaan keputusasaan apolegetik (apologetic hopeless), sebuah perasaan putus asa yang mencoba mencari sesuatu yang lain untuk dijadikan alasan sumpah serapah (scapegoating) dalam rangka melegitimasi keputusasaannya di hadapan orang lain.

Pengalamannya dengan kepahitan hidupnya, linkungannya, kegaggalan dalam karir dan kerjanya, dapat saja mendorong sesorang untuk melakukan perbuatan-perbuatan yang menyimpang dan anarkis. Perasaan yang menggunung akibat kegagalan hidup yang dideranya, mengakibatkan perasaan diri terisolasi dari 
masyarakat. Jika hal ini terus berlangsung tanpa adanya pembinaan dan bimbingan yang tepat. Orang tersebut akan melakukan perbuatan yang mengejutkan sebagai reaksi untuk sekedar menampakkan eksistensi dirinya. Dr. Abdurrahman al-Mathrudi pernah menulis, bahwa sebagian besar orang yang bergabung kepada kelompok garis keras adalah mereka yang secara pribadi mengalami kegagalan dalam hidup dan pendidikannya. Mereka inilah yang harus kita bina, dan kita perhatikan. Maka hendaknnya kita tidak selalu meremehkan mereka yang secara ekonomi dan nasib kurang beruntung. Sebab mereka ini sangat rentan dimanfaatkan dan dibrain washing oleh kelompok yang memiliki target terorisme tertentu.

d. Dendam Politikultur

Munculnya gerakan reformasi Islam di beberapa negaranegara Arab ketika berakhirnya Kerajaan Turki yang mana gerakan ini berusaha untuk memurnikan ajaran-ajaran dan praktek keagamaan umat Islam yang sekian lama terpengaruh oleh hegemoni kultur Barat yang mereka anggap sebagai budaya setan (evil cultur). Hegemoni ini tentu tidak terlepas dari kekuatan politik Barat yang hari ini telah mengalahkan kekuatan politik dunia Islam. Oleh karenanya kultur Barat haruslah dijauhi dan dianggap sebagai musuh, dan mereka harus diperangi sebagai balasan atas penindasan mereka terhadap umat Islam. Gerakan yang sama muncul juga di beberapa daerah Islam lainnya, seperti Gerakan Salafi yang menjadi representasi Wahabisme, Gerakan Mahdi di Sudan, Gerakan Sanusi di Afrika Utara, dan juga termasuk Gerakan Persatuan Islam di Indonesia.

e. Faktor Sejarah

Sejak Abad Kegelapan hingga Abad Pertengahan, upayaupaya untuk menaklukkan dan mengalahkan 
bangsa/masyarakat yang lemah merupakan bagian dari kebiasaan suatu bangsa atau kerajaan yang lebih kuat, sehingga kebiasaan tersebut dan seluruh akibatnya dapat diterima secara sah menurut pandangan politik dan hukum bangsa-bangsa pada masa itu. Fakta membuktikan betapa banyak sistem hukum dan kerajaan yang membenarkan praktek aneksasi tersebut, seperti hukum Yunani, Romawi, Bizantium, dan kerajaan kaum Frank, kerajaan Visighot, Ostrogoth, Mongol, negara-negara tentera salib, dan lain sebagainya yang saling menginvasi dalam kompetisi tiada henti demi untuk merebut kekuasaan dan mengokohkan dominasi dan hegemoni,9 termasuk apa yang dilakukan oleh kekhalifahan-kekhalifahan Islam awal. Realitas sejarah ini tentu saja berpengaruh pada pembentukan hukum Islam yang dimulai sejak abad ke $2 \mathrm{H}$ atau abad ke $8 \mathrm{M}$ dimana para ahli hukum (fuqaha) banyak memasukkan berbagai logika realitas sosial, politik dan ekonomipada masanya ke dalam interprestasi-interprestasi yang mereka lakukan terhadap Alquran dan hadis Nabi. Praktek-praktek kebenaran yang pada awalnya memang murni untuk kebaikan, namun kemudian berubah menjadi kebenaran yang digunakan untuk kejahatan (kebatilan) yang pada gilirannya melahirkan ilmu retorika bias politik yang dikuasai oleh kekhalifahan atas kepentingan relasi politik dan ekonomi. Dari sinilah lahir panji-panji palsu yang menggantungkan segala sesuatu kepada kepastian qadha dan qadhar secara artifisial dengan merubah konsep jihad menjadi perang eksternal dan penaklukan melalui ekspansi militer dan kekuatan senjata dengan cara membunuh pelaku makar hukum, dan mengarahkan peperangan eksternal atas nama jihad dan dakwah.10 Lebih jauh, sebagaimna dikatakan oleh Muhammad Syahrur bahwa retorika politik ini semakin kokoh dalam bentuknya yang mutakhir, dimulai dari Usman 
bin Affan (576-656H) dengan pernyataanya: "Aku tidak akan melepaskan 'baju' yang dipakaikan Allah kepadaku ...", dan kemudian diteruskan oleh para khalifah-khalifah Islam lainnya, seperti Abdullah bin Marwan (646-705M) yang menyatakan: "Saya tidak ingin mendengar seseorang yang berkata kepadaku 'bertakwalah kepada Allah', kecuali akan kupukul tengkuknya"; dan Abu Ja'far al-Manshur (95158H/714-775M) serta khalifah-khalifah sesudahnya yang memegang semboyan bahwa: "Sesungguhnya kami menghakimi kalian dengan kekuasaan Allah." Oleh karena itu, mereka mau tidak mau harus mengalihkan konflik internal menuju wilayah eksternal atas nama jihad.11 Dalam tradisi kerajaan Islam di Indonesia juga didapati berbagai istilah atau gelar berbau teologis yang diberikan kepada seorang raja ataupun sultan, seperti gelar zhillulah fi alardh,12 sehingga raja dianggap memiliki legitimasi ketuhanan untuk menentukan ataupun memberlakukan hukum dan kebijakan politik.

Selain beberapa factor yang telah dijabarkan diatas, masih ada beberapa factor yang melatarbelakangi mengapa tindakan radikal itu tumbuh dan berkembang di Indonesia seperti jamur yang tumbuh di musim penghujan.

Faktor tersebut antara lain :

\section{a. Faktor Pendidikan}

Sekalipun pendidikan bukanlah faktor langsung yang dapat menyebabkan munculnya gerakan terorisme, akan tetapi dampak yang dihasilkan dari suatu pendidikan yang keliru juga sangat berbahaya. Pendidikan agama khususnya yang harus lebih diperhatikan. Ajaran agama yang mengajarkan toleransi, kesantunan, keramahan, membenci pengrusakan, dan menganjurkan persatuan tidak sering didengungkan. Retorika pendidikan yang disuguhkan kepada ummat lebih sering bernada mengejek daripada mengajak, 
lebih sering memukul daripada merangkul, lebih sering menghardik daripada mendidik. Maka lahirnya generasi umat yang merasa dirinya dan kelompoknyalah yang paling benar sementara yang lain salah maka harus diperangi, adalah akibat dari sistem pendidikan kita yang salah. Sekolahsekolah agama dipaksa untuk memasukkan kurikulumkurikulum umum, sememtara sekolah umum alergi memasukan kurikulum agama, dan tidak sedikit orang-orang yang terlibat dalam aksi terorisme justru dari kalangan yang berlatar pendidikan umum, seperti dokter, insinyur, ahli teknik, ahli sains, namun hanya mempelajari agama sedikit dari luar sekolah, yang kebenaran pemahamananya belum tentu dapat dipertanggungjawabkan. Atau dididik oleh kelompok Islam yang keras dan memiliki pemahaman agama yang serabutan

b. Faktor Pemikiran

Yaitu merebaknya dua trend paham yang ada dalam masyarakat Islam, yang pertama menganggap bahwa agama merupakan penyebab kemunduran ummat Islam. Sehingga jika ummat ingin unggul dalam mengejar ketertinggalannya maka ia harus melepaskan baju agama yang ia miliki saat ini. Pemikiran ini merupakan produk sekularisme yang secara pilosofi anti terhadap agama. Sedang pemikiran yang kedua adalah mereflesikan penentangannya terhadap alam relaitas yang dianggapnya sudah tidak dapat ditolerir lagi, dunia saat ini dipandanganya tidak lagi akan mendatangkan keberkahan dari Allah SWT, penuh dengan kenistaan, sehingga satusatunya jalan selamat hanyalah kembali kepada agama. Namun jalan menuju kepada agama itu dilakukan dengan cara-cara yang sempit, keras, kaku dan memusuhi segala hal yang berbau modernitas. Pemikiran ini merupakan anak kandung dari pada paham fundamentalisme. Kedua corak pemikiran inilah yang jika tumbuh subur dimasyarakat akan 
melahirkan tindakan-tindakan radikal-destruktif yang kontra produktif bagi bangsa bahkan agama yang dianutnya.

c. Faktor Ekonomi

Problem kemiskinan, pengangguran dan keterjepitan ekonomi dapat mengubah pola pikir seseorang dari yang sebelumnya baik, menjadi orang yang sangat kejam dan dapat melakukan apa saja, termasuk melakukan terror, William Nock pengarang buku "Perwajahan Dunia Baru" mengatakan: Terorisme yang belakangan ini marak muncul merupakan reaksi dari kesenjangan ekonomi yang terjadi di dunia". Liberalisme ekonomi yang mengakibatkan perputaran modal hanya bergulir dan dirasakan bagi yang kaya saja, mengakibatkan jurang yang sangat tajam kepada yang miskin. Jika pola ekonomi seperti itu terus berlangsung pada tingkat global, maka yang terjadi reaksinya adalah terorisme internasional. Namun jika pola ekonomi seperti ini diterapkan pada tingkat Negara tertentu, maka akan memicu tindakan terorisme nasional.

d. Faktor Sosial

Diantara faktor munculnya pemahaman yang menyimpang adalah adanya kondisi konflik yang sering terjadi di dalam masyarakat. Banyaknya perkara-perkara yang menyedot perhatian massa yang berhujung pada tindakantindakan anarkis, pada akhirnya melahirkan antipati sekelompok orang untuk bersikap bercerai dengan masyarakat. Pada awalnya sikap berpisah dengan masyarakat ini diniatkan untuk menghindari kekacauan yang terjai. Namun lama kelamaan sikap ini berubah menjadi sikap antipati dan memusuhi masyarakat itu sendiri. Jika sekolompok orang ini berkumpul menjadi satu atau sengaja dikumpulkan, maka akan sangat mudah dimanfaatkan untuk kepentingan-kepentingan tertentu. Dalam gerakan agama sempalan, biasanya mereka lebih memilih menjadikan 
pandangan tokoh atau ulama yang keras dan kritis terhadap pemerintah. Karena mereka beranggapan, kelompok ulama yang memiliki pandangan moderat telah terkooptasi dan bersekongkol dengan penguasa. Sehingga ajaran Islam yang moderat dan rahmatan lil alamin itu tidak mereka ambil bahkan dijauhkan dan mereka lebih memilih pemahaman yang keras dari ulama yang yang kritis tersebut. Dari sinilah lalu, maka pemikiran garis keras Islam sesungguhnya sangat kecil, dan tidak mencerminkan wajah Islam yang sebenarnya. Namun gerakan dan tindakannya yang nekat dan tidak terkontrol, menjadikan wajah Islam yang moderat dan mayoriats itu seolah tertutup dan hilang.

e. Faktor Politik

Stabilitas politik yang diimbangi dengan pertumbuhan ekonomi yang berkeadilan bagi rakyat adalah cita-cita semua Negara. Kehadiran para pemimpin yang adil, berpihak pada rakyat, tidak semata hobi bertengkar dan menjamin kebebasan dan hak-hak rakyat, tentu akan melahirkan kebanggaan dari ada anak negeri untuk selalu membela dan memperjuangkan negaranya. Mereka akan sayang dan menjaga kehormatan negaranya baik dari dalam maupun dari luar. Namun sebaliknya jika politik yang dijalankan adalah politik kotor, politik yang hanya berpihak pada pemilik modal, kekuatan-kekuatan asing, bahkan politik pembodohan rakyat, maka kondisi ini lambat laun akan melahirkan tindakan skeptis masyarakat. Akan mudah muncul kelompokkelompok atas nama yang berbeda baik politik, agama ataupun sosial yang mudah saling menghancurkan satu sama lainnya.

Kemunculan semangat radikalisme tidak dapat dilepaskan dari berbagai faktor yang melatarbelakanginya. Salah satu penyebab utama dari munculnya radikalisme agama adalah pemahaman akan agama itu sendiri. Lebih 
jauh, Azyumardi Azra seperti dikutip Abdul Munip mengatakah bahwa radikalisme di kalangan Islam banyak bersumber dari:

a. Pemahaman kegamaan yang literal, sepotong-sepotong, parsial terhadap ayat-ayat al-Qur'an.

b. Bacaan yang salah terhadap sejarah Islam yang dikombinasikan dengan idealisasi berlebihan terhadap Islam pada masa tertentu.

c. Deprivasi politik, sosial dan ekonomi yang masih bertahan dalam masyarakat.

Kelompok radikal ini kemudian membawa pemahamannya sendiri ke tengah masyarakat dan berusaha mengartikulasikan dan mengimplementasikannya dalam wujud-wujud perubahan yang radikal terhadap tatanan sosialkeagamaan, seperti budaya Islamisasi, maupun tatanan politik dan hukum seperti proyeksi negara Islam, syariat Islam, ekonomi Islam dan sebagainya yang berbau Islam. Sebagian dari sikap ini dapat ditoleransi dan dibenarkan dalam wadah demokrasi, namun semangat berlebihan ini lebih banyak yang bersifat destruktif dan tidak dapat dibenarkan.Selanjutnya, untuk dapat mewujudkan cita-cita ideal tersebut, penyebaran faham radikalisme ini memanfaatkan sejumlah media yang ada, baik melalui gerakan politik, maupun gerakan civil society. Namun apapun bentuk gerakannya, salah satu ciri dan sekaligus menjadi basis utama gerakan ini adalah pendidikan melalui jalur pengkaderan yang terukur, penguasaan masjid, penggunaan media massa baik cetak maupun elektronik. Tentu tidak semua yang melakukan pengkaderan, berbasis di masjid, dan menggunakan media adalah gerakan radikalisme. 


\section{Implementasi Nilai-Nilai Pancasila Sebagai Asas Hukum Tertinggi dalam Mencegah Berkembangnya Tindak Radikalisme}

Dalam mencegah berkembangnya tindakan radikalisme diperlukan upaya-upaya yang menyentuh semua aspek kehidupan berbangsa dan bernegara, radikalisme bukan lagi persoalan lokal melainkan permasalahan nasional dan internasional. Di era reformasi, nilai-nilai Pancasila yang mulai ditinggalkan masyarakat perlu direvitalisasi, sedangkan segala bentuk radikalisme sendiri harus dideradikalisasi. Deradikalisasi yang paling utama dapat dilakukan adalah melalui implementasi nilai-nilai Pancasila secara utuh, mulai dari tahap sosialisasi, pemahaman, implementasi sampai ke aktualisasi Pancasila. Dengan adanya pemahaman, penghayatan, implementasi sampai aktualisasi Pancasila maka radikalisme agama akan tercerabut dari akarnya, karena radikalisme bukan nilai-nilai asli yang berasal dari cultural process masyarakat Indonesia.Upaya deradikalisasi melalui implementasi nilai-nilai Pancasila dapat dilakukan melalui metode bottom-up dengan menggali serta membangkitkan kembali nilai kearifan lokal yang selaras dengan Pancasila (deradikalisasi induktif) maupun dilakukan melalui metode top-down dengan negara sebagai aktor utama pendorong sosialisasi nilai-nilai Pancasila dengan menyediakan seperangkat aturan perundang-undangan yang mengikat, penciptaankesejahteraan masyarakat yang merata, serta turut memberikan dorongan motivasi kepada warga negara untuk selalu memelihara sikap kerukunan serta gotong royong dalam proses pencapaian tujuan nasional (deradikalisasi deduktif). Resultante dari dua metode deradikalisasi tersebut dapat secara efektif mencegah berkembangnya tindakan radikalisme karena selain didukung oleh revitalisasi nilainilai yang ada dari kearifan lokal juga didukung oleh negara 
sebagai aktor utama yang memberikan payung politik dalam implementasi nilai-nilai Pancasila.

Radikalisme dan terorisme merupakan sikap dan tindakan yang menakutkan dan menjadi momok bagi masyarakat luas. Terorisme terjadi karena cara pandang yang sempit, interpretasi yang tidak utuh terhadap ayat-ayat alQur'an serta manipulasi pelaku teror. Apabila terorisme dibiarkan tumbuh maka bisa menganggu kehidupan berbangsa, beragama, dan bernegara. Untuk itu agar terorisme dan radikalisme tidak berkembang maka diupayakan :

a. Pemerintah harus meciptakan kualitas dan taraf pendidikan yang baik, kesejahteraan masyarakat, hukum ditegakkan secara benar, dan pemerintah berwibawa.

b. Penguatan identitas dan kohesivitas kelompok ditemukan memiliki kontribusi yang relevan dalam bias proses pengambilan keputusan peledakan bom sebagai jihad. Keputusan itu lebih didorong oleh motivasional dan bukan rasional, sehingga rekonstruksi skema kognitif tertentu berkaitan dengan jihad bukan menjadi pilihan utama dalam kegiatan counter-terorisme. Menurunkan kohesivitas kelompok dan identitas kelompok merupakan merupakan langkah awal yang bermanfaat dalam mengurangi kecenderungan dihasilkannya keputusan dalam kelompok yang lebih beresiko dalam relasi antar kelompok.

c. Peminimalan akses terhadap berbagai permaslahan dan informasi yang dapat digunakan sebagai justifikasi, di antara dua penilaian ketidakadilan terhadap kelompok yang disebabkan oleh penindasan dan penganiayaan, pengurangan 
ancaman terhadap kelompok, serta akses yang terbuka untuk berperan serta dalam struktur sosial dengan sistem yang beragam tanpa mengabaikan pemenuhan kebutuhan mereka akan identitas muslim yang integralistik, akan berguna dalam mengembalikan mereka dalam strategi yang moderat dalam relasi antarkelompok yang bersifat kompetitif tersebut.

d. Sedangkan Azyumardi Azra, menyampaikan solusi komprehensif terorisme, antara lain dengan :

1) Melibatkan pendekatan sosio-kultural keagamaan memerlukan revitalisasi dan pemberdayaan pemberian kesempatan lebih besar dalam upaya solusi radikalisme dan terorisme. Denganrevitalisasi kepemimpinan ini, masyarakat bersangkutan dapat merajut kembali kohesi dan solidaritas sosial yang perlu untuk penguatan sistem dan mekanisme pencegahan dini dari infiltrasi anasir yang mengganggu pertahanan diri mereka.

2) Pembedayaan sosio-ekonomi masyarakat bersangkutan, khususnya remaja dan pemuda yang memang sangat rentan terhadap infiltrasi gagasan dan praksis radikalisme dan terorisme. Pendekatan ini dapat jadi langkah efektif mencegah terjerumusnya warga muda bangsa ke dalam tindakan merusak diri sekaligus negara-bangsa.

Dari sudut perspektif Pancasila dan kewarganegaraan, maka radikalisme merupakan masalah bagi demokrasikarena radikalisme bertolak belakang dengan nlai-nilai demokrasi. Setiap negara demokrasi dapat dipastikanadalah negara hukum sehingga radikalisme dan terorisme sebenarnya juga merupakan masalah serius dalam negara hukum. Prinsipprinsip dan nilai-nilai demokrasi sangat besar peranannya 
membentuk karaktermasyarakat baru yang diharapkan setelah reformasi. Masyarakat baru itu terbentuk melalui proses perubahansikap individu warga negara yang mencerminkan nilai-nilai demokrasi dan rasa hormat serta tanggungjawab yang juga ditandai oleh hal-hal berikut:

a. Menjunjung tinggi harkat, derajat dan martabat manusia sebagai sesama makhluk Tuhan Yang MahaKuasa

b. Mendahulukan kepentingan bersama tanpa mengabaikan kepentingan pribadi atau golongan

c. Menghargai pendapat orang dan tidak memaksakan pendapat kepada pihak atau orang lain

d. Menyelesaikan masalah secara musyawarah untuk mencapai kata mufakat, yang diliputi olehsemangat kekeluargaan

e. Menjunjung tinggi supremasi hukum dengan cara menaati norma hukum dan norma lainnya secarabertanggungjawab.I

f. Melaksanakan prinsip kebebasan disertai dengan tanggung jawab sosial kemasyarakatan

g. Mengutamakan persatuan dan kesatuan atau integrasi nasional

h. Tidak melakukan perbuatan-perbuatan yang diskriminatif atas dasar agama, ras, keturunan, jeniskelamin, status sosial, golongan politik.

Berhubung terorisme dan radikalisme sangat berkaitan dengan pola pikir dan bertindak, maka bagaimana seharusnyaberpikir yang berorientasi Pancasila dan bagaimana seharusnya hidup bersama sebagai masyarakat yangmenjunjung tinggi nilai religiusitas, kemanusiaan, persatuan, demokrasi dan keadilan dipahami dan dihayati.Tanpa hal tersebut maka ketrampilan dalam hidup berbangsa dan bernegara akan jatuh pada semangat 
yangbertentangan dengan pola berpikir dan nilai-nilai Pancasila, seperti pola pikir yang sempit,picik, negatif,kurang menerima keberadaan pihak lain, egosentris, eksklusif, memaksakan kehendak, dan main hakimsendiri.Romo Franz Magnis-Suseno pernah mengatakan bahwa rasa kebangsaan hanya akan dapatdipertahankan kalau satu syarat dipenuhi yaitu adanya kesediaan saling menerima dan saling mengakuidalam kekhasan masing-masing. Lebih lanjut dikemukakan bahwa kesediaan untuk saling menerima dalamperbedaan itulah merupakan komitmen inti bangsa Indonesia dalam Pancasila Mengingat teori sejarah di atas, maka terorisme dapat terulang kembali sebagaimana teori perputaran, tetapijuga mengalami perubahan dan variasi dalam tampilannya sesuai dengan kondisi dan situasi sebagaimanateori spiral. Motivasi dan sasaran terkadang tetap tapi juga berubah. Hal tersebut juga sangat ditentukan olehfaktor internal dan eksternal.

Metode deradikalisasi berupa "pengalihan sementara" tersebut pada kenyataannya tidak efektif dalam meredam tindak radikalisme, serangkaian teror dan tindak kekerasan yang mengatasnamakan agama masih sering terjadi. Oleh sebab itu pengintegrasian implementasi nilai-nilai Pancasila ke dalam metode deradikalisasi menjadi sangat penting, karena akan menyentuh tataran value, norms sampai behaviour suatu individu yang kemudian akan memberikan multiplier effect berupa terwujudnya masyarakat yang aman, tenteram dan damai.Metode deradikalisasi transformatif dengan implementasi nilai-nilai Pancasila berusaha menciptakan output yaitu masyarakat yang mengetahui jati diri dan karakternya sebagai bangsa Indonesia, memegang teguh ideologi Pancasila sebagai living ideology serta working ideology, sehingga menjadi masyarakat yang rasional dalam menghadapi segala tantangan perubahan 
zaman. Ideologi radikal yang terjadi seperti sekarang ini membuat masyarakat "putus asa" dan tidak rasional dalam menyikapi perkembangan zaman, semakin ketatnya kompetisi antar individu, kelompok maupun bangsa disikapi dengan cara-cara destruktif dan kontra produktif, sehingga bukan lagi kompetisi yang sehat untuk memenangkan pengaruh global, melainkan kompetisi yang tidak seimbang dengan menciptakan kondisi anarki yang kemudian diisi dengan nilai-nilai radikal.

Pelaku terorisme saat ini telah menyalahi nilai-nilai pancasila, terutama dalam Dalam sila Pertama, Ketuhanan Yang Maha Esa, dalam sila pertama, setiap warga negara wajib berketuhanan Yang Maha Esa, sikap saling menghormati dan bekerjasama antar umat beragama perlu diimplementasikan dalam kehidupan berbangsa dan bernegara, sebagai upaya menjalankan sila pertama dengan tujuan untuk menghindari praktik aksi terorisme dan kekerasan atas nama agama dengan tujuan menciptakan kerukunan antar umat manusia.Eksistensi manusia harus berdialog dalam hidup bersama melalui nilai-nilai pancasila yang pada nantinya akan membawa kedamaiaan, ketenteraman, dan penuh kasih sayang antar sesama manusia, dengan tujuan agar Tuhan pun mencintai manusia. Adapun yang menjadi pelanggaran terhadap Pancasila adalah :

a. Sila pertama Ketuhanan Yang Maha Esa ini mampu dilaksanakan dalam kehidupan berbangsa dan bernegera. Tentunya, aksi terorisme dapat dihindari sejak dini. Pancasila memuat makna keberagamaan dan kebersamaan yang dapat mencegah aksi terorisme.

b. Sila kedua, Kemanusiaan Yang Adil dan Beradab. Sila kedua ini menekankan bahwa setiap warga negara harus selalu menghargai harkat dan martabat orang lain, tidak boleh berbuat tercela menghina atau bahkan 
melakukan ancaman atau teror. Harkat dan martabat manusia harus dijunjung dengan cara yang adil dan beradab. Pengakuan atas harkat dan martabat kemanusiaan yakni kedudukan dan derajat yang sama. Saling mencintai sesama manusia.

c. Sila ketiga, upaya merajut rasa kebangsaan dan cara mengatasi persoalan terorisme harus dipererat kembali dengan mengimplementasikan sila ketiga atas pancasila dalam kehidupan berbangsa dan bernegara, sehingga aksi terorisme dapat diatasi dengan menggunakan pemahaman atas sila ketiga, yakni mengedepankan rasa kebangsaan bersama untuk persatuan dan kesatuan di antara warga negara Indonesia.

Dengan demikian, di tengah merebaknya tindakan terorisme dan radikalisme, pemerintah dan kepolisian harus bisa mencegah pelaku bomm bunu diri. Karena itu, pada saat ini bangsa Indonesia harus banyak melakukan banyak sosialisasi serta penghayatan dan pengamalan nilai-nilai pancasila, menumbuhkan nilai-nilai rasa kebangsaan dan rasa kewarganegaraan Indonesa harus dijadikan sebagai jalan memutus mata rantai aksi terorisme.

\section{Kesimpulan}

Banyak sekali factor yang membuat gerakan radikalisme ini terus bermunculan di Indonesia. Factor tersebut dapat disebabkan dari factor dalam diri manusia maupun dari luar diri manusia, dimana kedua factor tersebut adalah factor yang sama besarnya dalam mempengaruhi berkembangnya radikalisme dan terorisme muncul di Indonesia. Faktor factor tersebut antara lain :faktor internal keberagamaan, faktor eksternal sosio-politikultural, faktor psikologis, dendam politikultur, faktor sejarah, faktor pendidikan, faktor pemikiran, faktor ekonomi, faktor sosial dan faktor politik. 
Selain factor tersebut, masih terdapat factor lain, yaitu :Pemahaman kegamaan yang literal, sepotong-sepotong, parsial terhadap ayat-ayat al-Qur'an, Bacaan yang salah terhadap sejarah Islam yang dikombinasikan dengan idealisasi berlebihan terhadap Islam pada masa tertentu.dan Deprivasi politik, sosial dan ekonomi yang masih bertahan dalam masyarakat. Pancasila mempunyai berbagai macam fungsi dalam kehidupan pribadi, berbangsa dan bernegara, mempunyai peran yang sangat penting dalam menghalangi masuknya paham radikalisme dan terorisme di negara Indonesia, karena Pancasila mengandung nilai luhur yang dapat membentengi diri individu maupun negara dalam menghalau paham tersebut.

\section{Daftar Pustaka}

\section{Buku}

Abdul Wahid, et.al. 2004. Kejahatan Terorisme - Perspektif Agama, HAM dan Hukum. (Bandung : PT Refika Aditama).

Ali Imron. 2007. Ali Imron Sang Pengebom (Jakarta: Republika).

Departemen Pendidikan dan Kebudayaan. 1995. Kamus Besar Bahasa Indonesia , (Edisi Kedua), (Jakarta : Balai Pustaka).

Petrus Reinhard Golose. 2009. Deradikalisasi Terorisme: Humanis, Soul Approach, dan Menyenuh Akar Rumput(Jakarta: Yayasan Pengembangan Kajian Ilmu Kepolisian).

Ronny Nitibagaskara, 2006. Tegakkan Hukum Gunakan Hukum, (Jakarta: Penerbit Buku Kompas).

Sri Wuryan dan Syaifullah. 2009. Ilmu Kewarganegaraan (Civics), (Bandung : Laboratorium Kewarganegaraan Universitas Pendidikan Indonesia.) 


\section{Jurnal Ilmiah}

Abdul Munip, 2012. "Menangkal Radikalisme Agama di Sekolah", dalam Jurnal Pendidikan Islam Fakultas Tarbiyah dan Keguruan UIN Sunan Kalijaga Yogyakarta, Volume I, Nomor 2, Desember 2012.

Ansari Yamamah. 2015. Deradikalisasi Islam Indonesia : Gagasan Pemikiran Islam Transitif, Jurnal Analytica Islamica, Vol. 4, No. 2, 2015, Jurnal Universitas Islam Negeri Sumatera Utara.

Dede Rodin, 2016. Islam dan Radikalisme : Telaah Atas AyatAyat Kekerasan Dalam Al-Qur'an, Jurnal ADDIN, Vol. 10, No. 1, Februari 2016, Jurnal STAIN Kudus.

Farid Septian. 2010. Pelaksanaan Deradikalisasi Narapidana Terorisme di Lembaga Pemasyarakatan Kelas I Cipinang, Jurnal Kriminologi Indonesia, Vol. 7 No. 1 Mei 2010.

Fitriono, Eko Nani, dan Suhono Suhono. "Wacana Negara Islam: Kajian Kritis Kontruksi Pemikiran Khilafah Ala Hizbut Tahrir." Ri'ayah: Journal of Social and Religious 2, no. 02 (2017): 43-55.

Muhammad Agus Mushodiq, dan Suhono. "Ajaran Islam Nusantara Di Dalam Kamus Santri Tiga Bahasa Indonesia-Inggrisarab Karya Slamet Riyadi Dan Ainul Farihin (Studi Analisis Semiotika Dan Konsep Pribumisasi Islam Abdurrahman Wahid)." Jurnal Bahasa Lingua Scientia 9, no. 2 (2017): 210. https://doi.org/10.21274/ls.2017.9.2.209-240.

Mohamad Rapik. 2014. Deradikalisasi Faham Keagamaan Sudut Pandang Islam, Jurnal Inovatif, Volume VII Nomor II Mei 2014, Fakultas Hukum Universitas Jambi, 2014.

Muhammad Nursalim. 2014. Deradikalisasi Terorisme: Studi Atas Epistemologi, Model Interpretasi dan Manipulasi Pelaku Teror, Jurnal Kalam: Jurnal Studi Agama dan Pemikiran Islam Volume 8 Nomor 2 Tahun 2014, UIN Raden Intan Lampung.

Muh. Khamdan, 2015. Rethinking Deradikalisasi : Konstruksi Bina Damai Penanganan Terorisme, Jurnal ADDIN, Vol. 9, No. 1, Februari 2015, Jurnal STAIN Kudus. 
Reda Wicaksono. 2015. Implementasi Nilai-Nilai Pancasila Di Era Reformasi Dalam Mencegah Berkembangnya Tindak Radikalisme, Jurnal Polinter Vol 1, No 2 (2015), Pusat Penelitian Fakultas Ilmu Sosial dan Ilmu Politik Universitas 17 Agustus 1945 Jakarta, 2015.

Yosaphat Haris Nusarastriya. 2015. Radikalisme dan Terorisme di Indonesia dari Masa ke Masa (Tinjauan dari Perspektif Kewarganegaraan), Jurnal Pax Humana Vol 2, No 2 Mei 2015, (Yayasan Bina Dharma : Salatiga.

\section{Dokumen Elektronik}

Anonim, Pancasila Dan Terorisme, dikases dari http://pancasila.filsafat.ugm.ac.id/forums/topic/terorismedan-nilai-pancasila/, tanggal 28 Juni 2018 pukul 13.30 WIB.

Jejen Aqin, Bom Surabaya dan Upaya Pemerintah Melawan Terorisme, diakses dari https://geotimes.co.id/opini/bomsurabaya-dan-upaya-pemerintah-melawan-terorisme/ 